\title{
The Perception and the Effect of Using Concept Maps Strategy on English as a Foreign Language Learners'
}

\author{
Amir Aizuddin bin Sebi @ Hasbi, Nur Ehsan bin Mohd Said
}

\begin{abstract}
This research is to study the perception and also the effect of using concept maps strategy when the pupils use as foreign language. The case study was conducted in rural school in Malaysian Borneo which is situated in Sarawak whereby five samples were selected. The name of the school is Sekolah Kebangsaan Ulu Machan in Kanowit district and the pupils are all in Year Six which consists of five pupils. The instruments to collect the data from this case study are 'think aloud', one to one interview and the final instrument is group discussion where they manage to elaborate their perceptions towards the concept maps strategy and also the effect of the concept maps when they are using during English lesson in class takes place. The data from the analysis and finding found out that there was a positive improvement towards the strategy applied in class as in the analysis. To sum up, the usage of the concept maps strategy has brought the pupils of Year Six in the school improvement in essay writing.
\end{abstract}

Index Terms-Concept maps.

\section{INTRODUCTION}

Modernization is the key to improve self and mind. One may find it difficult to improve and follow the modernisation, but if one may follow it accordingly, it is not that hard as it sound. In education, it is similar with the modernisation itself. The evolution in education is important parallel to the modernisation and the current technology. Likewise, the curriculum in education also need to evolve from time to time. Malaysia has taken their role to update the education per se. Malaysia Education Blueprint is one of the finest and latest curriculum that has been implemented since 2013. Unfortunately, not all of the spectrums in the blueprint be followed throughout the country. There are still in a few places may not adequate to execute the blueprint entirely. Some of the schools in Malaysia still not have the equipments to carry the lesson as planned in the Malaysia Education Blueprint. Nonetheless, the initiative from the teachers in schools that make the lesson in class more interactive and interesting. One may combine with the current Information Communication and Technology (ICT) in the classroom and one may use all the teaching materials to ensure the classroom will be executed profoundly. The needing of the exploration

Amir Aizuddin bin Sebi@Hasbi, Department of Innovation in Teaching \& Learning, Faculty of Education, National University of Malaysia, Selangor, Malaysia.

Nur Ehsan Bin Mohd Said, Department of Innovation in Teaching \& Learning, Faculty of Education, National University of Malaysia, Selangor, Malaysia. for the new activities and methodologies in school are crucial for the educators to expand and execute their knowledge towards the pupils. The education in East Malaysia by far must be elevated parallel with the development of the demography area. Most part of East Malaysia still inadequate to comprehend the evolution of the curriculum in the Malaysia Education Blueprint. Schools in East Malaysia specifically in Sarawak may still not complete and conducive to disperse the new curriculum. In 2018, there are still rural school exists in Sarawak. Nevertheless, pupils in rural area are actively learning academically and co-academically despite the variation of the demography and socio economically.

\section{LITERATURE REVIEW}

\section{A. Concept Maps}

Using the concept maps to teach pupils in school now is instrumental so that they may acquire new reasoning skill and be critical in their thinking. Concept map has become increasingly popular teaching tools to all levels of education. For higher education students, they may need this knowledge to help themselves to understand better in their course and may give through explanation via the concept maps. Concept maps are graphical tools used for organising and representing knowledge (Novak and Canãs, 2008). It was first explored by Joseph Novak and his team at Cornell University in the 1970s, he claims that a graphic means of expressing scientific concepts to young children, it means the concept maps have been employed in a broad variety of settings and contexts, particularly but not exclusively in education. Concept maps help the pupils to externalise their prior knowledge and put together with the current knowledge by rearranging and internalising both form old to current knowledge in a graphic form (Schaal, 2010; Wu Hwang, Mildrad, Ke and Huang, 2012). The features of the concept maps are its hierarchical structure which point out specific concepts, most of the time in circles or boxes, and the connections of the line and dots between one idea to another indicates how ideas or specific concepts connects to one another. The most general and inclusive concepts are placed at the top of the map, while the secondary concept is placed below with the cross linkages and relationships between concepts indicated by lines (Wang, Lee and Chu, 2010). 


\section{B. Concept Maps In Practice}

Concept mapping has been proven to be a valuable cognitive tool in a variety of learning and instructional settings (Hsu \& Chang, 2009). Concept maps are used to communicate complex ideas and summarise information, for collaborative learning and for assessment and evaluation. Concept maps have been shown to help learners learn, researchers create new knowledge, administrators to better structure and manage organizations, writers to write, and evaluators to assess learning (Novak \& Cañas, 2008). Concept maps have also been used as advance organisers and as a curriculum development tool (Stoica, Morarum, \& Mironm, 2011).

Ausubel (1978) advocated the use of concept maps as advance organizers to foster meaningful learning. Advance organizers can be constructed by teachers or other experts for use by learners or they can be constructed by learners. For example, a concept map provided to the student can be a useful tool to communicate course content, while a concept map created by a student can assist them to organize and plan their own learning. Constructing concept maps allows the lesson designer to identify the key concepts in the planned lesson and the relationship between them. Novak (2010) suggests that using concept maps in planning curriculum or instruction on a specific topic helps to make the instruction conceptually transparent to students.

\section{RESEARCH Methodology}

This research will be a case study research as it only occur for five pupils involved in this research. The research site for this study will be in Sekolah Kebangsaan Ulu Machan, Kanowit, Sarawak (Ulu Machan National School). This school, consists of six prime classes which are from Year One until Year Six. Apart form that, there is also pre-school class which consists only one class. for Year One, there is one pupil, for Year Two consists of five pupils and for Year Three there are six pupils all together. Level two, in Year Four there are eight pupils, Year Five consists of five pupils and last but not least for Year Six, there are five pupils all together. The demography of this school: it is located $100 \mathrm{~km}$ away form the nearest town. To get to the school, the community needs to use the long boat and by using 15 horsepower of engine, it is approximately one hour to one an half hour, this time also need to consider the weather and also the river, if and only if the river is shallow, there will be more time to consume. All of the community in the long house are Iban and they devout to Christianity.

Qualitative research produces both exploratory and descriptive explanation (Hesse-Biber \& Leavy, 2010). One of the common ways to conduct a qualitative research is by conducting case studies. The case study seeks a holistic interpretation of the research problem in its context (Merriam, 2009). Case study research focuses on a single case or multiple cases as a whole unit as they occur in real life contexts (Johnson \& Christensen, 2007; Merriam, 2009; Yin, 2008). Case study has proven particularly useful for studying educational innovations, evaluation programmes, and in forming policy (Zainal, 2007). In this case study, I am going to conduct this case study together with all five pupils in Year 6. I may explore on how the pupils in the Year 6 implement concept maps as a learning strategy and how they perceive the usefulness of the concept maps in their studies.

\section{RESEARCH AIMS AND HYPOTHESES}

This research aims to know in-depth and overall perceptions' of five pupils in Year 6, which hold the concept maps and its relationships to their learning and to identity the factors from their experiences, contains or enhance from the usage of the concept maps. Two research questions guided research and investigations process. These are:

1. How do Year 6 pupils' understand the use concept maps?

2. How do they consider concept maps affects their learning?

\section{RESEARCH INSTRUMENTS}

Because Merriam (2009) claims that multiple methods of data collection are often used in case study research to triangulate data. In this case study, I will use three instruments to collect my data. Berg (2011) argues that when combining different method of data collection, the researchers obtain better and more substantial picture of reality because different methods reveal slightly different facets of the same symbolic reality. The three method that I will use are 'think aloud' sessions accompanied by one to one interview and the third one will be group discussion or 'focus group' interview which will aim to know in- depth of their perceptions' and their experience from the samples which are four male and one female in Year 6. Esterberg (2002) has mentioned understanding the learners' experience is the central component of a qualitative approach in education. By using all three instruments, I will gain information and also their perceptions' towards the usage of concept maps in class specifically in teaching writing skill for essay writing as their practice for the examination.

Using 'Think Aloud' session to the pupils of Year 6 is suitable for them as 'think Aloud' is a technique in which a person is asked to describe what they are doing while conducting the task. By given the information and a few lesson on how to use the concept maps, the samples may reveal their prior knowledge and their understanding of the task. Ericsson (2006) suggests that 'think aloud' sessions are useful in order to discover the cognitive processes that take place during learning activities. I will using this 'Think Aloud' as my first instrument to obtain the informations from the pupils. And, by using 'Think Aloud' they may give direct answer and honest answer as they will use the verbal prompt that may find it interesting as interactive. Apart from that, it may suit to the pupils as to encourage them to speak freely and allow them to express their deep thoughts of their new 
and perceptions in their own words (Esterberg, 2002). This session will be conduct with the combination of their mother tongue which is Iban Language and a little bit of Malay and English.

Besides, after 'Think Aloud' is carried out, the next instrument will be the interview on one to one basis. A research interview is an activity where a researcher and participant engage in a conversation to obtain a special kind of information (Merriam, 2009). Interviews are frequently used in educational research to provide researchers with an opportunity for detail investigation of participants' personal perspectives (Kvale, 2009). Cohen, Manion, and Morrison (2007) note that interviews enable participants to express how they regard situations from their own point-of view and to discuss their interpretations of the world in which they live. Radnor (2002) uses Cannell and Kahn's (1968, cited in Radnor, 2002) definition of the research interview as "a two-person conversation initiated by the interviewer for the specific purpose of obtaining research relevant information" to emphasise the focused aspect of conversation undertaken as part of the research process. By doing as such, it help to the researcher to find the answers and their perceptions towards the concept maps. During interview session, the researcher will get more informations about the samples experience and the their point of view and also to raise the issue during 'Think Aloud' session. An interview guide was used to provide this focus and to maintain consistency between the sub-cases (Johnson \& Christensen, 2007; Stake, 2005). Ritchie and Lewis (2003) note that semi-structured interviews enable the interviewer to ask key questions and then to do some additional probing for further information. The duration for the 'Think Aloud' session and the interview session, it could take approximately 50-60 minutes. Interview will be note taken my myself and also it will be recorded using voice recorder in Smartphone to enhance and allow the researcher the researcher to focus on the interviews and capture the data accurately.

As for the third one will be the questionnaire, there will a questionnaire for them to answer and with that, the data collection will correlate to one another, after they done their interview session and 'Think Aloud' session, the researcher will provide the questionnaire as to support their experience and the understanding of using the concept maps. The questions are simple for them to understand and also it will reflect from the interview and also 'Think Aloud' session. By the three information that may taken from it, the researcher may triangulate the data and come to the finding and the conclusion for the overall of the perceptions towards using the concept maps to inhale their understanding and their experience from using the concept maps.

\section{RESEARCH PARTICIPANTS}

The participants involved in this research are the a group of pupils in Year 6 of Sekolah Kebangsaan Ulu Machan. In the year of 2018, there are only five pupils of Year 6 that will sit for the established examination which is Ujian Penilaian Sekolah Rendah (UPSR). All of them are from rural area which are living in the Long House nearby the school located. According to Yin (2008), achieving the greatest understanding of the phenomenon depends on choosing the case(s) well. In this scenario, I am selected my sample to carry this case study. It is supported by Creswell (2008), he mentions that to choose well purposive sample is applied by many qualitative researchers. Moreover, in this method, the researchers do not randomly select the sample of their study but they select the research participants in a strategic way so that the sample is relevant to answer the research questions (Bryman, 2012). This study is compose by five pupils of Year 6 and the race for all of them is Iban and they devout to Christianity as for their religion. Ritchie and Lewis (2003) suggest that purposive sampling is particularly suitable for the studies which involve subjects with particular features. As my options are also limited, that is also one of the reasons for this participants happen to be all Year 6 and also I am teaching them as well for English as one of the major subjects for them to sit in the established examination.

\section{ANALYSIS AND FINDINGS}

\section{A. Experience and Perspectives}

In this case study, we will follow closely to the research questions and how it link to one another and to form as a conclusion about their perception and the effects of using the concept maps in learning English as a Foreign Language. The research questions which are:

1. How do Year 6 pupils' understand the use concept maps?

2. How do they consider concept maps affects their learning?

\section{B. The Case Study}

\section{CASE STUDY A : ANDREAN ANAK BALANG}

Andean is the eldest son in his family. He only has two siblings and his sister is younger one old than him. Andrean' parents live in the city, he and his sister live with his grandparent in the long house. He is been staying in school hostel since he is in Year One. During school holidays and weekend then only he staying in the long house with his grandparent. Among Andrean and his friends, he is the top of his class especially in English.

Andrean believed that concept maps helped his to analyse information and to illustrate the similarities as well as the differences between concepts:

"I find this strategy a useful way to organise my learning and maximise the mind potentials, to cope with the enormous amount of information involved in university study." 
In the think aloud session Andrean was able to quickly identifyconcepts, though he did not always identify the relationship between the concepts. He confessed that he often did not write down the relationship between concepts when constructing a map Andrean was fully aware that this could cause a problem later on when he needed to remember the type of relationship between concepts on her map.

Andrean believed that using concept maps not only helped him in his studies but that they also encouraged him to become a better critical thinker and self-learner. What he liked most about concept maps was that they facilitated the process of memorising by arranging ideas graphically using shape, colour and sometimes images. Andrean believed that concept maps contributed fun to his study, especially when the map-creation was placed as a student group activity:

"Working in a group benefits me so much, we can get information from each other and together learn more".

Clearly, Andrean is fast learner and he easily relate the issue and make his own point in the concept maps. He finds that using the concept maps is much connivence for him to organising his ideas before he starts to write his essay. Apart from that, before this, he does not know at all about this concept maps, previously he just directly write the essay with making the concept maps. Moreover, he also answers that the effect of using the concept maps enhance his understanding towards English better and faster.

He also claim that, during the discussion among peers, he easily detect the weakness and the incomplete informations from his friend and also he may asks his friends about the ideas that his friend try to convey. He also helps his friends to generate ideas and use the concept maps not only during English lesson, but the manage to try to use it during other subjects as well. During the 'Think Aloud' session also he is the one that giving more responses compared to his friends.

\section{CASE STUDY B : ATHANASIUS BETAU ANAK BENETH}

Betau also the eldest in his siblings, he has one sister three years younger than him. He is quite fortunate, he lives with his parents at long house and his mother is the staff in the school. The level of proficiency is basic same with all of them.

Betau believed that concept maps were useful to organise information and also made information easy to remember especially when he used different shapes and colours to identify different concepts. He liked the fact that concept maps consisted of fewer words than texts which makes the subject easier to understand and to remember. Betau found concept maps was easily to be done. He argued that "without utilising concept maps, I could not know to do essay".

He argued in 'Think Aloud' session that "[At first] I thought that concept maps are the same as mind maps, but I realised that there is a huge difference between them".

Betau made use of concept mapping to support his learning and considered it to be one of his most useful learning strategies. Although he did not use concept maps as much as she would have liked to, Betau believed that students needed more help to understand the process of concept mapping and the usefulness of concept map as a learning strategy.

Betau understood the difference between mind map and concept map very well. However, he found it difficult when creating concept maps, to identify the relationship between concepts without help. The main barriers she faced were a lack of English proficiency and insufficient training in using concept maps.

\section{CASE STUDY C : HARY ANAK NGUMBANG}

Hary is a passive boy in the class, but when it comes to complete task, he is one of the pupils that will submit the task on time. He has five siblings and he is the third from five of them. He is actively in sports and also curriculum acitvities. His parents live secluded and not living in the long house, but they live in the orchard. Most of his free time, he is just spending the time helping his parents in the orchard and during school time, he stays at the school hostel.

Although he was new to using concept maps, Hary made an effort to create and to use concept maps in his study. Hary believed that although he could do all his study without using concept maps, he needed to work hard arranging his thoughts, especially with very complex and complicated essay. He said concept maps helped him to sort ideas and to retrieve information faster and more thoroughly. Hary also found that using concept map help him to gain a better understanding in his studies because concept maps helped him to organize information and to remember them. The concept maps were particularly useful during examination time as they enabled easy memorisation of facts. Hary also found that making a concept map reduced his tension about the overload of study in the school.

Hary recognised that concept maps illustrated the relationships between information and was able to identify the type of relationship when concept mapping. He used concept maps principally as a summarising device and for revision. In addition to seeing concept maps as a good means of organising information, Hary believed that concept maps help him to develop his study skills. He found that the use of concept maps especially pen and paper concept maps helped her to focus more in getting the main ideas from texts.

Hary found that the use of concept maps especially pen and paper helped him to concentrate on his studies for a longer period and supported his learning. He enjoyed working in group with other pupils and found that using concept maps in a group discussion really made ideas easy to understand. 


\section{CASE STUDY D : NICHOLAS ROSALES ANAK NAPIT}

Rosales has seven siblings he is the youngest, he is not staying in the hostel instead he stay with his parents at the long house. He is quite fortunate as his parents afford to buy him necessary items compared to their friends. The background of the family is almost similar to the rest from their friends. He is not talkative during both session, but I manage to get a few information from him after his asked him about his perception about using the concept maps in the lesson.

Rosales used concept mapping as one of his learning strategies and was confident in constructing a concept map, although his understanding of concept maps was affected by early confusion between mind maps and concept maps. He considered that concept maps also helped him to think critically about the relationship between concepts and in this way developed her critical thinking skills.

\section{CASE STUDY E : PAULA ANAK CHEMING}

Paula is the only girl in the family. She has five siblings and most of this brothers are not at his place, so she is usable at home and easily for her to concentrate doing homework and revision. She is staying with his parent as her long house is just nearby to the school compare to her friend.

However, when dealing with a difficult and complicated subject, she found it very hard to organise all the important information in just one map. She used concept maps to memorise new vocabulary.

Paula liked to use concept maps in her study because she said she could not remember information unless she linked it to shapes and colours, which helped her to remember better than just words. Paula reported that:

"For me, it is much easier to remember a picture- the picture tends to stick to my mind for a long time"

In the think aloud session, Paula demonstrated a good understanding of concept maps. Using pen and paper, Farah quickly identified the concepts she wished to highlight and the relationships between them. She was able to explain how her map was arranged and why she had placed the different concepts in relation to each other.

Paula used concept maps effectively as a learning strategy. She used them to make study plans, summarise lessons and organise her research. She found that it was very helpful to use concept maps in her learning. . Paula had a good understanding of how concept maps could be used and could make different kinds of concept maps by using different colours and shapes. She believes that concept maps helped her to concentrate longer in her learning. She claims that it was also easier for her to memorise and recall information when she organized the information in a concept map.

\section{Emerging Themes}

The analysis of the think aloud sessions, subsequent interviews and questionnaire show some clear recurring themes. It is clear that:

The samples found concept mapping to be a useful method for managing and understanding complex topics. Concept maps are considered to be a useful teaching and learning tool.

The samples considered that explicit training was needed to know how to construct and understand concept maps successfully.

Lack of English language proficiency and critical analysis skills were seen as limiting factors in the participants' ability to construct concept maps.

Peer support and collaborative concept mapping helped participants both to increase participants' understanding of their subject areas and how to understand and how to construct concept maps.

\section{CONCLUSION}

Based from the case study that carried out in rural school, it is cleanly the concept maps bring huge significant to the pupils to engage the task in the examination per se. They have considered that using the concept maps, it can saves their time and as well the essay become organised and can be presented in well mannered. This case study find that the six pupils in Year six use the concept maps in a various ways to support their learning, it has become a successful tools to elaborate, summarise, and organise for their writing an essay. Also, not for just merely in preparing to write an essay, it also one of the ways to conduct discussion, group work, peer task as well as individual assignment. Most of the pupils in Year six as whole agree that the concept maps affected their learning and improved their understanding from a simple topic to compel topic.

Moreover, they also believe that by having the skill of creating concept maps, it also may increase the level of their critical thinking. They become more actively in class, they may ask questions to fulfil the need of completing their concept maps, discussion between educators, and peers also become more active and creative in term of giving productive answers and ideas. These finding also support by the previous research with the consistency and existing research and literature about concept maps which argues that concept maps is a flexible and learning strategy (Laight, 2014) which assists in the development of creative and critical thinking skills (Novak and Canãs, 2007).

Moreover, they have become more creative in doing the concept maps by making it more colourful and cartoonish to attract themselves to read and easy to understand once they have creating the concept maps. At the end of the day, during the result of Established Examination comes out, all of them 
in Year 6, excel in English, none of them flunk in the English paper, it means that it really helpful and meaningful learning they have achieved.

\section{REFERENCES}

[1] Afamasaga-Fuata "i, K. (2009). Concept mapping in mathematics: Research into practice. Springer.

[2] Ageel, M. (2011). The ICT proficiencies of university teachers in Saudi Arabia: a case study to identify challenges and encouragements. Hummingbird, (2), 55-60.

[3] Akinsanya, C., \& Williams, M. (2004). Concept mapping for meaningful learning. Nurse Education Today, 24(1), 41-46.

[4] Âhlberg, M. (2004). Varieties of concept mapping. In A.J. Cañas, J.D. Novak \& F.M. González (Eds.), Concept maps: Theory, methodology, technology. Proceedings of the 1s International conference onconcept mapping. Pamplona, Spain: Universidad Públia de Navarra. Retrieved May March 30, 2013 from http://cmc.ihmc.us/papers/ cmc2004-206.pdf.

[5] Al-Rashdan, A.-F. A. (2009). Higher Education in the Arab World: Hopes and Challenges. Arab Insight Journal, 2(6), 77-90.

[6] Ardito, C., De Marsico, M., Lanzilotti, R., Levialdi, S., Roselli, T., Rossano, V., \& Tersigni, M. (2004). Usability of e-learning tools. In Proceedings of the working conference on Advanced visual interfaces (pp. 80-84). Retrieved from http://dl.acm.org/ citation.cfm?id=989873

[7] Ausubel, D. P. (1978). In defense of advance organizers: A reply to the critics. Review of Educational Research, 48(2), 251-257.

[8] Berg, L. B. (2001). Qualitative Research Methods for the Social Sciences. Boston: Allyn and Bond.

[9] Brown, D. S. (2003). High school biology: A group approach to concept mapping. The American Biology Teacher, 65(3), 192-197.

[10] Bryman, A. (2012). Social research methods (4th ed.). New York. United States: Oxford University Press

[11] Buzan, T. (1974). Use your head. British Broadcasting Corporation.

[12] Cañas, A. J., \& Novak, J. D. (2006). The effects of "concept mapping" on second

[13] language learners" comprehension of informative text. In A. J. Cañas, J. D. Novak \& F. M. González (Eds.), Concept Maps: Theory, Methodology,Technology.

[14] Proceedings of the 2nd International Conference on Concept Mapping., San José, Costa Rica.

[15] Cañas, A. J., Novak, J. D., \& González, F. M. (2004). Teaching by doing with concept maps. In A. J. Cañas, J. D. Novak \& F. M. González (Eds.),Concept Maps: Theory, Methodology,Technology. Proceedings of the 1st International Conference on Concept Mapping. Pamplona, Spain:Universidad Pública de Navarra. Retrieved July 13, 2013, from http://cmc.ihmc.us/papers/cmc2004-145.pdf

[16] Cañas, A. J., Novak, J. D., González, F. M., \& Conceição, S. (2004). Learning style and critical thinking in an online course that uses concept maps. In A. J. Cañas, J. D. Novak \& F. M. González (Eds.),Concept Maps: Theory, Methodology,Technology. Proceedings of the 1st International Conference on Concept Mapping. Pamplona, Spain:Universidad Pública de Navarra.

[17] Carnot, M. J., Feltovich, P., Hoffman, R. R., Feltovich, J., \& Novak, J. D. (2003). A summary of literature pertaining to the use of concept mapping techniques and technologies for education and performance support. Technical Report submitted to

[18] The Chief of Naval Education and Training Pensacola FL, Retrieved July 2nd , 2012 from https://carmenwiki.osu.edu/download/

[19] Literature+Review+on+Concept+Mapping.f

[20] Chang, K. E., Sung, Y. T., \& Chen, S. F. (2001). Learning through computer-based concept mapping with scaffolding aid. Journal of Computer Assisted Learning, 17, 21-33.

[21] Chularut, P., \& DeBacker, T. K. (2004). The influence of concept mapping on achievement, self-regulation, and self-efficacy in students of English as a second language. Contemporary Educational Psychology, 29(3), 248-263.

[22] Cicognani, A. (2000). Concept mapping as a collaborative tool for enhanced online learning. Educational Technology \& Society, 3(3), $150-158$.

[23] 1 Cohen, L., Manion, L., \& Morrison, K. (2007). Research Methods in Education. (6th ed.). London: Routledge.

[24] Creswell, J. W. (2008). Research design: Qualitative, quantitative, and mixed methods approaches. Thousand Oaks, CA: Sage Publications.

[25] De Simone, C., Schmid, R. F., \& McEwen, L. A. (2001). Supporting the learning process with collaborative concept mapping using computer-based communication tools and processes. Educational Research and Evaluation, 7(2-3), 263-283.

[26] Denzin, N. K., \& Lincoln, Y. S. (2007). Collecting and interpreting qualitative materials. Thousand Oaks, CA: Sage Publications.

[27] Egan, B. (2012). International Education as a Conduit for Engagement between Countries: The Case of Saudi Students in New Zealand (A thesis submitted in fulfilment of the requirements of the Degree of Doctor of Philosophy in International Business). University of Auckland, New Zealnad.

[28] Eppler, M. J. (2006). A comparison between concept maps, mind maps, conceptual diagrams, and visual metaphors as complementary tools for knowledge construction and sharing. Information Visualization, 5(3), 202-210.

[29] Ericsson, K. A. (2006). Protocol analysis and expert thought: Concurrent verbalizations of thinking during experts" performance on representative tasks. The Cambridge handbook of expertise and expert performance, (pp. 223-241).

[30] Esterberg, K. G. (2002). Qualitative methods in social research. McGraw-Hill Boston.

[31] Retrieved July 15th, 2012 from http://orton.catie.ac.cr/cgibin/wxis.exe/? IsisScript=SIBE01.xis\&method=post $\&$ formato $=2 \&$ cantidad

[32] Forehand, M. (2010). Bloom"s taxonomy. Retrieved February 20th, 2013 from http:// projects.coe.uga.edu/epltt/index.php?title=Bloom\%27s_Taxonomy

[33] Freeman, L. A., \& Jessup, L. M. (2004). The power and benefits of concept mapping: measuring use, usefulness, ease of use, and satisfaction. International Journal of Science Education, 26(2), 151-169.

[34] Gokhale, A. A. (1995). Collaborative learning enhances critical thinking. Journal of Technology Education. 6(1). Retrieved December 10th , 2012 from http://

scholar.lib.vt.edu/ejournals/JTE/v7n1/gokhale.jte-v7n1.html?ref=Saw os.Org

[35] Golafshani, N. (2003). Understanding reliability and validity in qualitative research. The qualitative report, 8(4), 597-607. Guild, P. B., \& Garger, S. (1998). Marching to Different Drummers. USA: ASCD. 134

[36] Gul, R. B., \& Boman, J. A. (2006). Concept mapping: A strategy for teaching and evaluation in nursing education. Nurse Education in Practice, 6(4), 199-206.

[37] Gutierrez, K. D., \& Rogoff, B. (2003). Cultural Ways of Learning: Individual Traits or Repertoires of Practice. Educational Researcher, 32(5), 19-25.

[38] Hakuta, K. (1986). Mirror of language: The debate on bilingualism. New York: Basic Books.

[39] Hay, D. B. (2007). Using concept maps to measure deep, surface and non-learning outcomes. Studies in Higher Education, 32(1), 39-57.

[40] Hesse-Biber, S. N., \& Levy, P. (2006). The practice of qualitative research . Thousands Oaks: Sage

[41] Hsu, C. M., \& Chang, I. H. (2009). The Relationship between Computer-Based Concept Mapping and Creative Performance. Asian Journal of Arts and Sciences, (86), 16-36.

[42] Hwang, G. J., Shi, Y. R., \& Chu, H. C. (2010). A concept map approach to developing collaborative Mindtools for context-aware ubiquitous learning. British Journal of Educational Technology, 42(5), 778-789.

[43] Jankowska, M. (2010). Enabling student development: with socially mediated concept mapping technique. Journal for Learner Development in Higher Education, Special

[44] Edition: Researching PDP Practice, Retrieved September 15th , 2012 from www.aldinhe.ac.uk/ojs.

[45] Johnson, B., \& Christensen, L. (2007). Educational research: Quantitative, qualitative, and mixed approaches. Thousand Oaks, CA: Sage Publications.

[46] Jones, B. D., Ruff, C., Snyder, J. D., Petrich, B., \& Koonce, C. (2012) The effects of mind mapping activities on students" motivation. International Journal for the Scholarship of Teaching and Learning, 6(1). Retrieved from http:// eaglescholar.georgiasouthern.edu:8080/jspui/handle/10518/4884

[47] Joy, S., \& Kolb, D. A. (2009). Are there cultural differences in learning style? International Journal of intercultural relations, 33(1), 69-85.

[48] Kao, G. Y.-M., Lin, S. S., \& Sun, C.-T. (2008). Breaking concept boundaries to enhance creative potential: using integrated concept maps for conceptual self-awareness. Computers \& Education, 51(4), $1718-1728$.

[49] Keppens, J., \& Hay, D. (2008). Concept map assessment for teaching computer programming. Computer Science Education, 18(1), 31-42. 
[50] Khiabani, M. N., \& Nafissi, Z. (2010). Promoting EFL Learners ${ }^{e e}$ Academic Motivation and Reading Comprehension via Portfolio Development of Concept Maps. Retrieved

[51] April 1st, 2013 from http://www.sid.ir/En/VEWSSID/J_pdf/1032120100204.pdf

[52] Kim, P., \& Olaciregui, C. (2008). The effects of a concept map-based information display in an electronic portfolio system on information processing and retention in a fifth- grade science class covering the Earthes atmosphere. British Journal of Educational Technology, 39(4), $700-714$.

[53] Kostovich, C. T., Poradzisz, M., Woood, K., \& OBrien, K. L. (2007). Learning style preference and student aptitude for concept maps. Journal of Nursing Education, 46(5), 217-224.

[54] Krueger, R. A., \& Casey, M. A. (2009). Focus groups: A practical guide for applied research (4th ed.). Thousand Oaks: Sage Publications.

[55] Kvale, S. (2009). Interviews: An Introduction to Qualitative Research Interviewing. London: Sage.

[56] Kwon, S. Y., \& Cifuentes, L. (2007). Using Computers to Individually-generate vs. Collaboratively-generate Concept Maps. Educational Technology \& Society,10 (4), 269-280.

[57] Laight, D. W. (2004). Attitudes to concept maps as a teaching/learning activity in undergraduate health professional education: Influence of preferred learning style. Medical Teacher, 26(3), 229- 233.

[58] Liu, C. C., Chiang, S. H. F., Chou, C. Y., \& Chen, S. Y. (2010). Knowledge exploration with concept association techniques. Online Information Review, 34(5), 786-805.

[59] Liu, P.-L. (2011). A study on the use of computerized concept mapping to assist ESL learners ${ }^{\text {ee }}$ writing. Computers \& Education, 57(4), 2548-2558.

[60] Longcamp, M., Boucard, C., Gilhodes, J.-C., \& Velay, J.-L. (2006). Remembering the orientation of newly learned characters depends on the associated writing knowledge: A comparison between handwriting and typing. Human movement science, 25(4), 646-656.

[61] MacKinnon, G. (2006). Contentious issues in science education: Building critical thinking patterns through two-dimensional concept mapping. Journal of Educational Multimedia and Hypermedia, 15(4), 433-445.

[62] Mahnam, L., \& Nejadansari, D. (2012). The Effects of Different Pre-Writing Strategies on Iranian EFL Writing Achievement. International Education Studies, 5(1),154- 160.

[63] Mangen, A \&Velay, J-L. (2010). Digitizing Literacy: Reflections on the Haptics of Writing,

[64] Advances in Haptics, Mehrdad Hosseini Zadeh (Ed.), Retrieved January 25th , 2013

[65] from http://www.intechopen.com/books/advances-inhaptics/digitizing-literacy- reflections-on-the-haptics-of-writing

[66] Maxwell, J. A. (2004). Qualitative research design: An interactive approach. Thousand Oaks, CA: Sage Publications.

[67] McLintock, A. H., William Hosking Oliver, M. A. (N Z. ), \& Taonga, N. Z. M. for C. and H. T. M. (n.d.). The Colombo Plan. An encyclopaedia of New Zealand, edited by A. H

[68] McLintock, 1966. Web page. Retrieved March 16th , 2013, from http:// www.teara.govt.nz/en/1966/international-relations/page-4

[69] Merriam, S. B. (2009). Qualitative research: A guide to design and implementation. San Francisco. Jossey-Bass.

[70] Miller, R. L., \& Brewer, J. D. (2003). The AZ of social research: a dictionary of key social science research concepts. Thousand Oaks, New Delhi: Sage Publications.

[71] Moon, B. M., Hoffman, R. R., \& Novak, J. (2011). Applied concept mapping: Capturing, analyzing, and organizing knowledge. Boca Raton, FL: Taylor \& Francis.

[72] Moreira, M. A. (2011). Why concepts, why meaningful learning, why collaborative activities and why concept maps? Aprendizagem Significativa em Revista/ Meaningful Learning Review, 1(3), 1-11.

[73] Moreira, M. M., \& Moreira, S. M. (2011). Meaningful learning: use of concept maps in foreign language education, Aprendizagem Significativa em Revista/Meaningful Learning Review, V1(2), 64-75.

[74] Moreno, R. (2010). Educational Psychology. Hoboken, NJ: John Wiley and Sons.

[75] Morgan, D. L. (1996). Focus groups as qualitative research. Newbury Park, California: Sage Publications.

[76] Novak, J. D. (2010). Learning, creating, and using knowledge: Concept maps as facilitative tools in schools and corporations. Hillsdale, NJ: Lawrence Erlbaum.

[77] Novak, J. D., \& Cañas, A. J. (2004). Building on Constructivist Ideas and CmapTools to Create a New Model for Education. In A. J. Cañas, J. D. Novak \& F. M. González (Eds.),Concept Maps: Theory, Methodology,Technology. Proceedings of the 1st International
Conference on Concept Mapping. Pamplona, Spain:Universidad Pública de Navarra.

[78] Novak, J. D., \& Cañas, A. J. (2006). The origins of the concept mapping tool and the continuing evolution of the tool. Information Visualization, 5(3), 175-184

[79] Novak, J. D., \& Cañas, A. J. (2007). Theoretical origins of concept maps, how to construct them, and uses in education. Reflecting Education, 3(1), 29-42.

[80] Novak, J. D., \& Cañas, A. J. (2008). The theory underlying concept maps and how to construct and use them. Technical Report IHMC CmapTools. Florida Institute for Human and Machine Cognition. Retrieved May18, 2012 from http://www.ssu.ac.ir/ fileadmin/templates/fa/Moavenatha/MoavenateAmozeshi/edicupload/olymp-3.pdf.

[81] Novak, J. D., \& Gowin, D. B. (1984). Learning how to learn. New York: Cambridge University Press.

[82] Ottenbreit-Leftwich, A. T., Glazewski, K. D., Newby, T. J., \& Ertmer, P. A. (2010). Teacher value beliefs associated with using technology: Addressing professional and student needs. Computers \& Education, 55(3), 1321-1335.

[83] Radnor, H. (2002). Researching your professional practice. Doing Interpretive Research. Milton Keynes, UK: Open University Press.

[84] Ritchie, J., \& Lewis, J. (2003). Qualitative Research Practice: A Guide for Social Science Students and Researchers. London: Sage.

[85] Royer, R., \& Royer, J. (2004). Comparing hand drawn and computer generated concept mapping. Journal of computers in mathematics and science teaching, 23(1), 67-81.

[86] Rueda, U., Arruarte, A., Elorriaga, J. A., \& Herran, E. (2009). Learning the attachment theory with the CM-ED concept map editor. Computers \& Education, 52(2), 460-469.

[87] Ruffini, M. F. (2008). Using e-maps to organize and navigate online content. Educause Quarterly, 31(1), 32- 56.

[88] Ryan, G. W., \& Bernard, H. R. (2000). Data management and analysis methods. In N. K. Denzin \&Y. S. Lincoln (Eds.), Handbook of qualitative research(2nd ed., pp. 769- 802). Thousand Oaks,CA: Sage.

[89] Safar, A. H., Alqudsi-Ghabra, T. M. \& Qabazard, N. M.(2012). Use of Concept Mapping and Visual Learning Software in Education at Kuwait University. Education, 132(4). 834-861.

[90] Samovar, L. A., Porter, R. E., \& McDaniel, E. R. (2009). Communication between cultures. Belmont, CA: Wadsworth

[91] Trifone, J. D. (2006). To What Extent can Concept Mapping Motivate Students to Take a More Meaningful Approach to Learning Biology? The Science Education Review, 5(4).1-23.

[92] Vita, G. D. (2001). Learning styles, culture and inclusive instruction in the multicultural classroom: A business and management perspective. Innovations in Education and Teaching International, 38(2), 165-174.

[93] Vural, O., \& Zellner, R. (2010). Using Concept Mapping in Video-Based Learning. Gaziantep University Journal of Social Sciences, 9(3), 747-757.

[94] Wang, W.-C., Lee, C.-C., \& Chu, Y.-C. (2010). A brief review on developing creative thinking in young children by mind mapping. International Business Research, 3(3), 233- 238.

[95] Wu, P. H., Hwang, G. J., Milrad, M., Ke, H. R., \& Huang, Y. M. (2012). An innovative concept map approach for improving students ${ }^{\text {ee }}$ learning performance with an instant feedback mechanism. British Journal of Educational Technology, 43(2), 217-232.

[96] Yamani, M. (2002). Challenged by example: globalisation and the new Arab awakening.

[97] Toby Dodge/Richard Higgott (Hg.): Globalization and the Middle East Islam, Economy, Society and Politics. London: The Royal Institute of International Affairs, 113-131.

[98] Yen, J. C., Lee, C. Y., \& Chen, I. (2012). The effects of image-based concept mapping on the learning outcomes and cognitive processes of mobile learners. British Journal of Educational Technology, 43(2), 307-320.

[99] Yin, R. K. (2008). Case study research: Design and methods (3rd ed.). Thousand Oaks, CA: Sage.

[100]Zainal, Z. (2007). Case study as a research method. Jurnal Kemanusiaan,1 (9), 1-6. 140 